\title{
THE IMAGO TEMPLI OF THE INVISIBLE CHURCH: IDEALISM AND ABSTRACT ART.
}

\section{«IMAGO TEMPLI» DE LA IGLESIA INVISIBLE: IDEALISMO Y ARTE ABSTRACTO}

\author{
Haris Ch. Papoulias ${ }^{1}$ \\ UNED Madrid (Spain)
}

\begin{abstract}
Two events, apparently distant one from the other and without any direct link between them, but nevertheless strictly connected by a common spiritual legacy, constitute the subject of this paper. The first one, took place in 1971, when a very special «ecumenical chapel» opened its doors to the public. It is known under the name of «Rothko Chapel», due to the general project, undertaken by the painter Mark Rothko. Since that time, it has become one of the most precious artworks that represent the contemporary religious aesthetics. The black Rothko's paintings, the Greekcross building designed by the architect Philip Johnson, the Broken Obelisk of the artist Barnett Newman standing right out of the Chapel and the music composed for this ambient by the composer Morton Feldman, have replaced what traditionally has been called an «imago templi»; but contrary to all Christian tradition they represent (literally) no-thing. The second event, took place in 1795, when two young friends, Hegel and Schelling, were making a kind of oath under the sign of an Invisible Church, actualizing an ambiguous concept that, even if rooted in the Holy Scriptures, it had been condemned for its consequences as heretical. The relationship between these two events is given by contemporary art historians which have established that modern abstract painting, from a formal point of view, is rooted in the Romantic tradition. With this paper I would like to contribute to the establishment of this connection, not only by formal means, but by showing a common spiritual attitude towards images. Christianity, essentially figurative in its religious aesthetics, has always had to deal with the Jewish prohibition of image-making. This difficulty has been inherited to contemporary debates in which artist with classical readings and education, often of Jewish origins but active in Christian societies, try to create a new kind of art, above all traditions and free of dogmas. According to my suggestion, Rothko Chapel should be considered as the realization of a fragile balance in which both «aniconism» and «need of images» have simultaneously sublated their one-sidedness, producing a high-
\end{abstract}

[1] Haris Ch. Papoulias es doctor en filosofia por la Universidad del Piemonte Oriental, y Doctor Europaeus (Universidad de Málaga). Actualmente colabora en el proyecto de investigación de la Cátedra Internacional de Hermenéutica Crítica «HERCRITIA-Santander» de la UNED-Madrid. Sus líneas de investigación son el idealismo alemán, con especial dedicación a la filosofía hegeliana, y las teorías de la imagen contemporáneas.Su email es haris.papoulias@yahoo.it. 
er spiritual stage. Thus, such a chapel would not be a simple space where all religions could only meet and undertake a dialog, but should be considered as something more surprising: a unique realization of what logically appears as a pure contradiction: the realization of an Imago Templi for an Invisible Church.

Key words:Rothko; Hegel; Abstract Art; Idealism; Invisible Church

Abstract: Dos eventos, aparentemente distantes uno del otro y sin vínculos directos entre ellos, pero sin embargo estrictamente relacionados por un legado espiritual común, constituyen el tema de este trabajo. El primero, tuvo lugar en 1971, cuando una «capilla ecuménica» muy especial abrió sus puertas al público. Es conocida bajo el nombre de «Rothko Chapel», debido al proyecto general, realizado por el pintor Mark Rothko. Desde entonces, se ha convertido en una de las obras de arte más valiosas que representan la estética religiosa contemporánea. Las pinturas negras de Rothko, la planta del edificio de "cruz griega» diseñado por el arquitecto Philip Johnson, el obelisco del artista Barnett Newman y la música compuesta para este ambiente por el compositor Morton Feldman, han reemplazado lo que tradicionalmente ha sido llamado «imago templi»; pero, contrariamente a toda tradición cristiana, representan nada (literalmente: no-thing). El segundo evento, tuvo lugar en 1795, cuando dos jóvenes amigos, Hegel y Schelling, estaban haciendo una especie de juramento bajo el signo de una Iglesia Invisible, actualizando un concepto ambiguo que, incluso arraigándose en las Sagradas Escrituras, ya había sido condenado por las iglesias oficiales por sus consecuencias heréticas. La relación entre estos dos eventos está dada por historiadores del arte moderno que han establecido que la pintura abstracta, desde un punto de vista formal, tiene sus raíces en la tradición romántica. Con este trabajo me gustaría contribuir al establecimiento de esta conexión, no solo por medios formales, sino también mostrando una actitud espiritual común hacia las imágenes. El cristianismo, esencialmente figurativo en su estética religiosa, siempre ha tenido que lidiar con la prohibición judía de la creación de imágenes. Esta dificultad ha sido trasferida a los debates contemporáneos en los que artistas con lecturas y educación clásicas, a menudo de origen judío pero activos en sociedades cristianas, intentan crear un nuevo tipo de arte, fuera de toda tradición y sin dogmas. Según mi sugerencia, Rothko Chapel debería considerarse como la realización de un equilibrio frágil en el que tanto el «aniconismo» como la «necesidad de imágenes» han superado su mutua unilateralidad, produciendo una etapa espiritual más elevada. Por lo tanto, tal capilla no sería un simple espacio donde todas las religiones podrían solo reunirse y dialogar, pero debería considerarse algo más sorprendente, es decir, una realización única de lo que lógicamente aparece como una pura contradicción: la realización de un Imago Templi para una Iglesia Invisible.

Key words: Rothko; Hegel; Arte Abstracto; Idealismo; Iglesia Invisible 
To the Artists Union «Comitato di Salute Pubblica» (Perugia, Italy), where I learned that «a picture lives only by companionship».

Clearly the Rothko chapel is a dangerous place for philosophy. James Elkins ${ }^{2}$.

\section{Introduction to the Invisible through the Visible: Cara- vaggio's lesson.}

If we shall visit Villa Borghese in Rome today, we could admire, among others, a Caravaggio painting called La Madonna dei Palafrenieri (or Madonna and Child with St. Anne, 1605-06 - see: Figure 1). The visual politics of Counter-Reformation

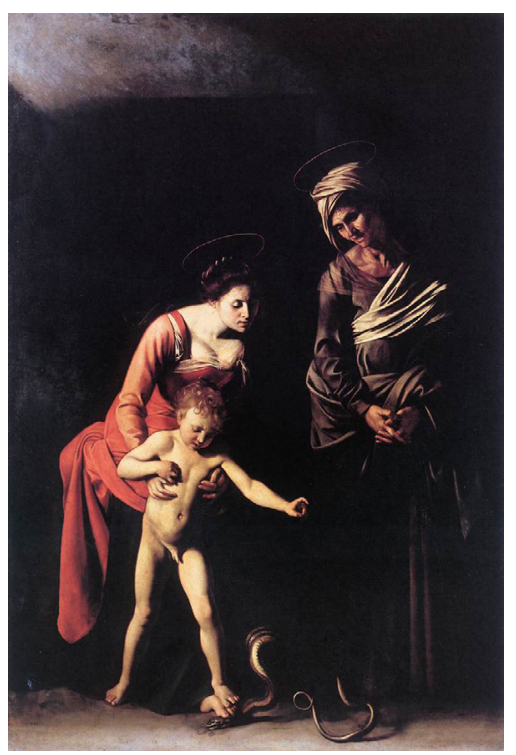

Figure 1: Michelangelo Merisi da Caravaggio, La madonnna de palafrenieri, 1605-06, oil on canvas, $(292 \times 211 \mathrm{~cm})$, Galleria Borghese, Roma. are paradigmatically represented in this painting; perhaps much too paradigmatically: in fact, the painting has been removed from its altar because of the realism of the flesh; and Cardinal Borghese took it in his private collection.

Little pleats and shadows on Mary's dress sketch her body and her breasts vividly; Jesus is uncommonly grown-up and his body is not that of a baby anymore. The scene represented is a common topic in Christian iconography and it has nothing special in itself ${ }^{3}$. Saint Anne, for instance, was simply the protector of the Archconfraternity of Palafrenieri for which the painting was made.

From an iconological point of view, what is interesting for our purpose is the lower part of the canvas, where a snake appears out of the dark room where the whole scene is situated. The snake, as in the biblical story of Eden, is the symbol of sin, corruption, and death. In Genesis $(3,14-15)$ is written:

[2] James Elkins, Pictures and Tears: A History of People Who Have Cried in Front of Paintings (New York and London: Routledge, 2005) 16.

[3] Actually it is influenced by another painting of Ambrogio Figino; for some details on the intellectual background of Caravaggio, see: Daniele Radini Tedeschi, Caravaggio o della Vulgata, De Luca ed., Firenze 2011. 
(14) And the Lord God said unto the serpent, Because thou hast done this, thou art cursed above all cattle, and above every beast of the field; upon thy belly shalt thou go, and dust shalt thou eat all the days of thy life: (15) And I will put enmity between thee and the woman, and between thy seed and her seed; it shall bruise thy head, and thou shalt bruise his heel.

The last verse speaks about a double enmity: between the woman and the snake, but also between her seed and the snake's seed. However, what will defeat the snake will not actually be the woman but «her seed». Luther, with his always sharp mind, said that this seed is just Christ and only Christ; that is to say, the Evil will be defeated not by what the biblical woman represents (as a prophetic reference to Holy Mary and so to the «Visible» Church) but by Christ (the seed of Mary) alone. This is another aspect of the well-known Lutheran polemics against the so called intercession of the saints ${ }^{4}$. Pope Pius V $(1504-1572)$ formalized the catholic version in a papal bull by affirming that of course it is Jesus who extirpates the Evil but through the intercession of Mary (and so of the Church) . $^{5}$

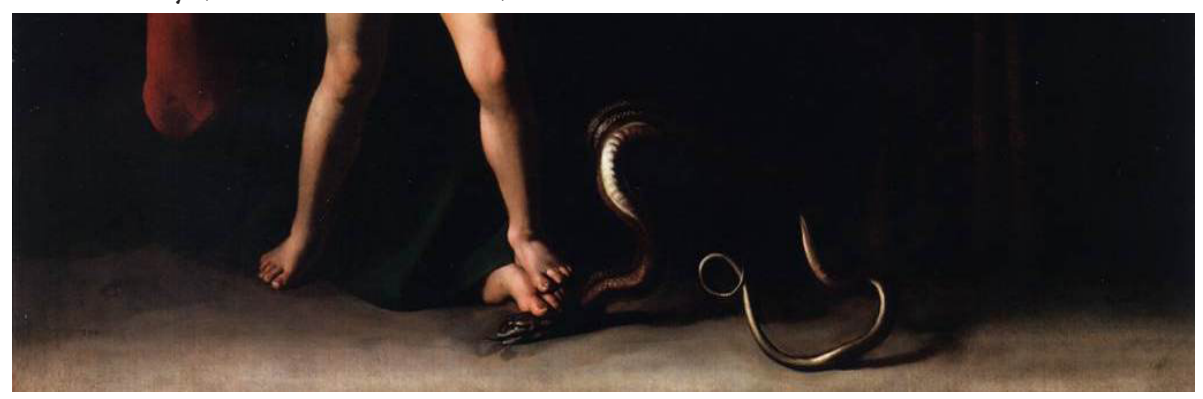

Figure 2: La Madonna dei Palafrenieri, detail.

The detail [figure 2] with the foot of Mary as medium between the foot of Jesus and the head of the snake could be considered as the image par excellence of the Counter-reformation's doctrine. In a certain way it is a further explanation through a symbolic act of what is supposed to be the very essence of an image: a necessary medium between God and us. Modern painting will take this medium off not only because the symbol is not efficient anymore, but because the essence of the image turned out to be something different than a simple medium. Without any mediation by the Visible, sometimes the contemporary image seems to be less and blind to our concrete spiritual research, like a blackboard where everything could be written, forms without a content; or sometimes seems to be more, something like an immediate access to the Mystery. What follows has the purpose to reflect on this ambiguity.

[4] See for instance: M. Luther, Ein sendbrief D. M. Luthers. Von Dolmetzschen und Fürbit der heiligenn in: Dr. Martin Luthers Werke, (Weimar: Hermann Boehlaus Nachfolger, 1909), Band 30, Teil II, pp. 632-646; usually translated in English with the title An Open Letter on Translating.

[5] «For she by her seed has crushed the head of the twisted serpent, and has alone destroyed all heresies»; see: Pope Pius V, Consueverunt Romani, $\$ 1$. 
More particularly, the aim of this essay is to present one of the most significant contemporary Imago Templi and to interpret it not through psychological notions that arise from the subjective contemplation of paintings, but by turning back to the last great era of Philosophy, the era of German Idealism. In that way, we should search for the roots that made possible the appearance of such a particular chapel, out of any traditional canon of religious art. For that reason, I will not suggest to the reader, as many art critiques often do, how he/she has to feel in front of an abstract painting, if he/she has to weep, to be confused or to feel ecstasy. These attitudes are of no help for the comprehension of an image, but only create contemporary myths ${ }^{6}$. They reduce the works of art to psychological products to be consumed by the masses, and all the truth that every image carries inside seems to be shrunk in a personal mood where anything could become a metaphor for everything.

Nevertheless, moving from 1960's or 1970's to the beginnings of the Nineteenth century, a premise would be useful in order to capture the connection between these two distant historical periods: Idealism and Abstract Art. Contemporary research in Art History has established that the origins of abstraction are to be found in the northern romantic tradition. Robert Rosenblum and Francesco Arcangeli are the two pioneers that explained in the 1970's, almost simultaneously, how the common formal aspects between distant historical periods express an inner, a mental, or a spiritual common attitude as well. ${ }^{7}$ And when we do not treat simply single paintings but a chapel that soon became one of the symbols of contemporary spirituality, then the idea lying behind becomes important for the determination of our own spiritual identity.

[6] The reader could find a well-balanced treatment of the overestimated reaction of weeping in front of a painting in the book just mentioned: J. Elkins, Pictures and Tears, 2-17. Most of the times, a wide-spread opinion drives us to perpetuate uncritical attitudes in front of an artwork. But the demolition of such opinions does not mean a demystification of Art in a negative sense. With a sense of humor and irony, Elkins writes: «Maybe I didn't cry because I left too soon, before the chapel could undermine the few ideas I had left. Maybe I was thinking about philosophy too much, or trying too hard to be an assiduous scholar. Or perhaps it was because I kept myself busy noting other people's tears: I was like a doctor who tries to be sympathetic, but is too professional to really feel anything. So if I hadn't behaved like a doctor, or a philosopher (or a doctor of philosophy!) I might have cried...perhaps. I'm not sure if any of those are good explanations» (p.16).

[7] See: R. Rosenblum, Modern Painting and the Northern Romantic Tradition: Friedrich to Rothko (Thames and Hudson, 1978). In the same years in which Rosenblum was giving his lectures that later became the book just mentioned, in Italy another important Art Historian, Francesco Arcangeli, was developing the very same idea during his lectures at the University of Bologna; see F. Arcangeli, Dal romanticismo all'informale (Bologna: Alfa, 1976). 


\section{The Rothko Chapel: religious Art without Religion.}

February 1971. Rothko Chapel opens its doors to the public. But the artist to whom the Chapel owes its name, Mark Rothko, committed suicide only a few months before. As somebody said, Rothko "paid the consequences for being a mystic in an era characterized by the absence of faith». ${ }^{8}$ Fortunately, in this attempt he was not completely alone: many important personalities contributed to the creation of this uncommon spiritual set, and it would be our obligation to mention them rapidly.

Besides the realization of the panels inside the Chapel, Rothko directed also the general architectonical project, in collaboration with the architects Philip Johnson, Howard Barnstone and Eugene Aubry. But it was Rothko himself that chose an octagonal plan-configuration, inscribed in a Greek cross. It is said that this style was inspired by the Byzantine Church of Santa Fosca, Torcello in Venice, visited by Rothko during one of his travels in Italy. ${ }^{9}$ Outdoors, there is a reflecting pool and a standing steel sculpture of Barnett Newman, called Broken Obelisk. Morton Feldman, created original music to accompany the meditation in the Chapel which soon became a classical piece of contemporary music. The patrons that conceived and financed the idea were the couple Dominique and John De Menil ${ }^{10}$.

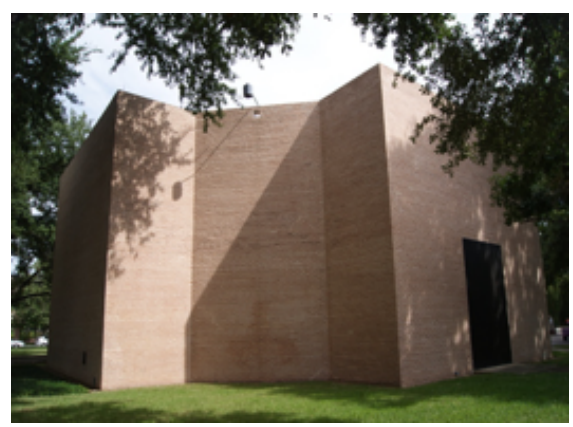

Fig. 3. Rothko Chapel, Houston, Texas.

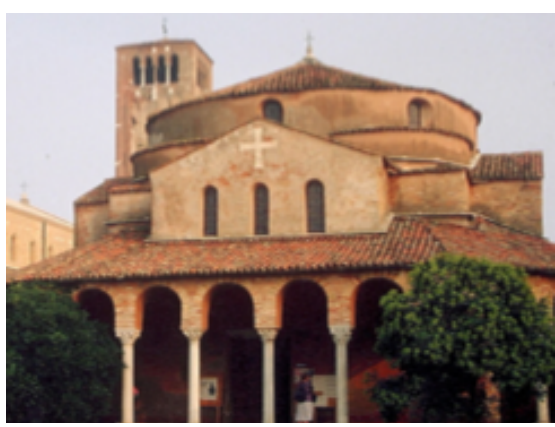

Fig. 4. Santa Fosca, Torcello, Venice, Italy.

Mark Rothko, born Markus Yakovlevich Rotkovich, is considered to be one of the most important American painters. He belongs to the generation of the Abstract Expressionists of New York. Born in Russia in 1903, he migrated to the United States

[8] John Golding, Paths to the Absolute: Mondrian, Malevich, Kandinsky, Pollock, Newman, Rothko, and Still (Princeton: Princeton University Press, 2000); Spanish translation: Caminos a lo absoluto. Mondrian, Malèvich, Kandisky, Pollock, Newman, Rothko y Still (Madrid: Turner, 2003) 223.

[9] See: James E. B. Breslin, Mark Rothko: A Biography (Chicago: University of Chicago Press) p. 465. Nonetheless, we should notice that Santa Maria Assunta has not an octagonal plan; it is more probable that Rothko was referring to Santa Fosca, another small Byzantine church right next to Santa Maria Assunta.

[10] Many interesting details on the whole project can be found in the official website of Texas Historical Commission, http://atlas.thc.state.tx.us/view_narrative.aspx?narrative $=00000883$.htm\&title $=$ Rothko $\% 20$ Chapel\&filepath=E:|atlas_text|nr_listed \html [Accessed: 20 June 2015]. 
when he was 10 years old. He was of Jewish origin, as Barnett Newman and Adolph Gottlieb, the other major Abstract Expressionists. Jewish origin is often recalled to explain the aniconic tendency of modern art, and in that case, Rothko's source of inspiration too. Of course, there is a certain relation, but we should admit that «an artist's interest in Kabbalistic doctrines does not in itself make his art Jewish». ${ }^{11}$ Barnett Newman, for instance, did not believe in the existence of a Jewish art at all. ${ }^{12}$ Mark Rothko actually was soaked in notions taken from the classical Greek heritage, as for instance, his main inspiration, the Greek tragedy. ${ }^{13}$ In any case, all Jewish artists left behind their roots in the same way that contemporary Christians did, in order to achieve a new conception of spirituality, beyond the contradiction of a figural or non-figural representation of God, and that is the point, I think, that makes their contribution unique in the History of our Aesthetics.

It is a matter of fact that most of the artists of this generation begun their career as figurative painters. Events such as the Second World War, the Holocaust and the atomic bomb led progressively to the loss of faith in human subject. In the $40 \mathrm{~s}$, Surrealism was guiding the dissolution of the figure. Rothko himself admitted that «a time came when none of us could use the figure without mutilating it». ${ }^{14}$ This was commonly called the "Age of Anxiety». As in some of Rothko's early paintings, in the underground, people were transformed into ghosts. The «spiritual» was not out in heaven anymore, but inside the «dark well of the existence», as Hegel would say. All that we call the «identity of a subject», its conscious life, its intelligence, its auto-determinacy, its free Will, were undermined by the unconscious, or by every animal instinct and tendency. I believe that the real violence against the subject was this figural mutilation. The complete absence of human figure in the Abstract Expressionism is not a continuation of this violence. On the contrary, it is a new religious art, not adaptable to any visible Church. In a secular world, all abstract expressionists searched for a new language to be able to express again the divine. This is a sense of divine that survived, even if in an indeterminate condition, after the crisis of metaphysics in the post-modern thought. Newman said «I hope that my painting has the impact of giving someone (...) the feeling of his own totality, of his own separateness - of his own individuali-

[11] Antony Julius, Idolizing Pictures: Idolatry, Iconoclasm, and Jewish Art (Thames \& Hudson, 2001) 44.

[12] See for instance, the novel by Potok in which is described a family drama of a young Jewish child that dreams of becoming a painter; Chaim Potok, My Name Is Asher Lev (New York: Knopf, 1972); Newman, when asked by Arthur Cohen what he thought about Jewish art, answered: «Not very much, not very interesting if there is such a confection, and it is doubtful that there ever was»; cited in Mark Godfrey, «Barnett Newman's Stations of the Cross and the memory of the Holocaust», in Melissa Ho (ed.), Reconsidering Barnett Newman (New Haven and London: Yale University Press, 2005) 46.

[13] On the importance of this notion in Rothko's works, see: Amador Vega, Sacrificio y creación en la pintura de Rothko (Madrid: Siruela 2010).

[14] Mark Rothko, speaking at the Pratt Institute; first published in The New York Times, 31 October 1958, now in the Tate Gallery catalogue: Mark Rothko, (London: 1987) 76-89. 
ty. $\rangle^{15}$ These declarations are to be taken against the loss of the subject in modern art, against what Sedlmayr called Verlust der Mitte, loss of the center, even if they do not reproduce the old solutions that the Christian tradition, or Sedlmayr himself, would have wished for ${ }^{16}$. Against the European art that expressed the crisis, we should recognize the American painters that tried to restore an ideal lost for a long time in the Old World: the use of the image as an introduction to the Truth. An «introduction», not because it is something «less» than other forms of knowledge, but because only Art has the power to initiate this process and detach human beings from the poverty and limitedness of the sensible Present.

However, it is really hard to overcome this Presence and the means of Art are always fragile. The most common objection that reflects the strong engagement of our eyes with this Presence can be easily understood behind people's complaint that there is nothing to see in abstract paintings. They want to see the "Cathedra» of God in Newman's painting, ${ }^{17}$ for instance, and they are searching for a material throne or at least for a kind of sofa, similar to their living room. But when we give them a Cathedral, as those in the paintings of Friedrich, ${ }^{18}$ what do they really see? Are they really «visible Churches»? (See fig. 5, 6, 7)

Observe, in those paintings, how in the lowest third of the canvases, there is always a clear separation between the earthly element and the heavenly one; the Cathedrals are grounded on the latter and not on the "world's wisdom». Friedrich opposes the ruins of the old visible Church (i.e. the Roman-Catholic Church), to the new, spiritual and alive Invisible Church. ${ }^{19}$ Our eyes, not educated anymore, see figures and we think that they see also the meaning. What do we really see in a picture like the Woman at a window ${ }^{20}$ (See An immediate answer says: it is Friedrich's studio, and the woman is Caroline, his wife. By observing her dress or her haircut we could understand her social class, her background, etc. But if these are the only things we see, we have not seen anything.

[15] Barnett Newman: Selected Writings and Interviews (University of California Press, 1992) 257-8.

[16] This «slogan» (Die Mitte verlassen, heißt die Menschlichkeit verlassen) was of the Art Historian Hans Sedlmayr (see his: Verlust der Mitte, Salzburg - Wien: Otto Müller Verlag, 1948; English translation: Art in Crisis: The Lost Center, London, 1957) and was taken from B. Pascal's Pensées (C'est sortir de l'humanité que de sortir du milieu; frag. 518, ed. Lafuma). Sedlmayr was a severe critique of modern art, but not for the trivial reasons they attributed to him (Nazi ideology of pure art etc.). His main point against modern art was exactly the same of many Christian thinkers from the Eighth Century to our days: the loss of the Human figure and the loss of the Subject.

[17] See Newman's painting Cathedra, 1951, in the collection of the Stedelijk Museum of Amsterdam.

[18] See Friedrich's paintings such as: The cross on the mountain (1812, Kunstmuseum at Düsseldorf); The Cathedral (1818, Museum Georg Schäfer, Schweinfurt); Vision of the Christian Church (1820, Museum Georg Schäfer, Schweinfurt).

[19] See Hugh Honour, Romanticism (Westview Press, 1979) 158.

[20] Woman at a Window (1822, Alte Nationalgalerie, Berlin). 


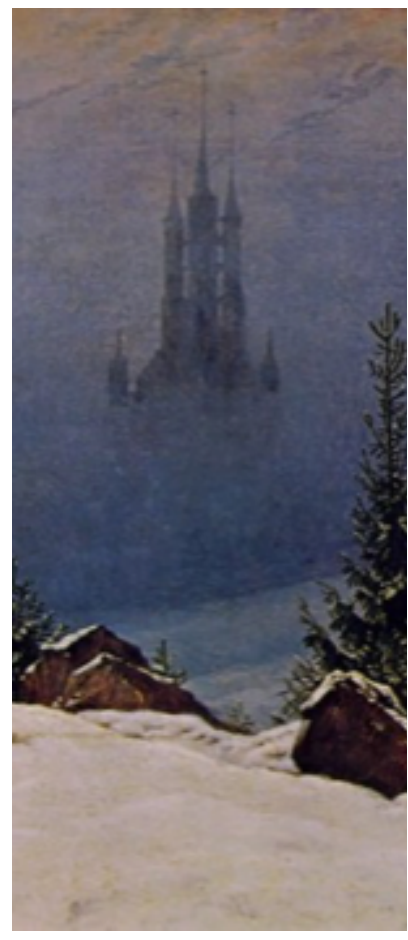

Fig. 5. Winter Landscape, 1811, de- Fig. 6. The Cathedral, 1817, detail; oil on canvas, $33 \times 45 \mathrm{~cm}$,

Museum fur Kunst und Kulturgeschichte, Dortmund, Germany.

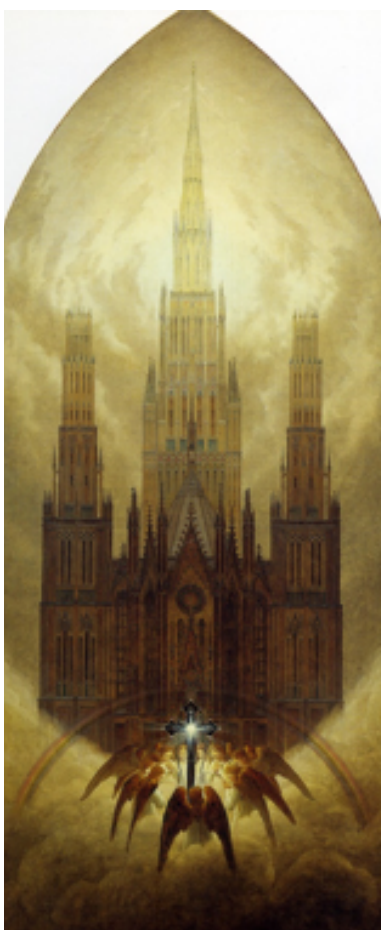
tail; oil on canvas, $152,5 \times 70,5 \mathrm{~cm}$ G. Schäfer Collection, Obbach bei Schweinfurt, Germany.

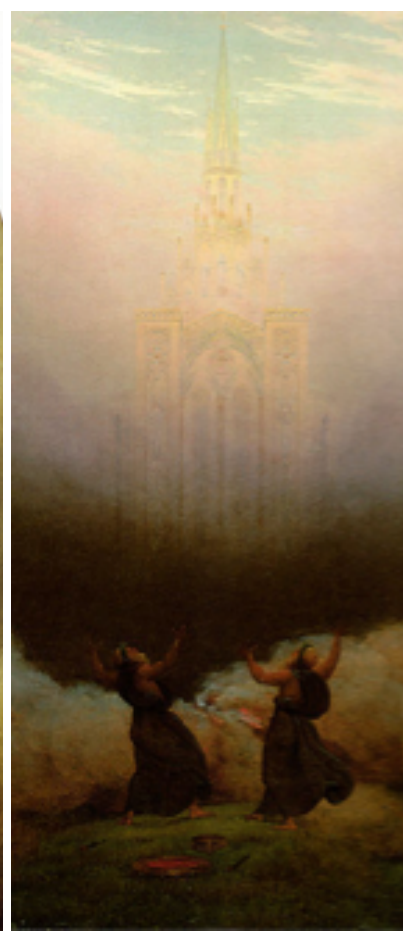

Fig. 7. Vision of the Christian Church, 1820, detail; Oil on canvas, $66.5 \times 51.5 \mathrm{~cm}$;

G. Schäfer Collection, Obbach bei Schweinfurt, Germany.

In reality, the painter has posited us in a point of view which, from the darkness of the room (our interiority), leads us to the «outer world», to the spectacle of life; it is from out there that light enters through the sign of the cross (faith and sacrifice). The natural and the spiritual light are here tight together in a symbolic way of representation: the light comes into our darkness through pain and sacrifice. We understand that there is a river outside because of the ship-mast glimpsing out of the window. That river, recalls the navigatio vitae, ${ }^{21}$ the journey of existence, towards the other side, through death to the afterlife, where the poplar trees are (in the background of the window), standing as symbols of transfiguration. The naive picture of a welldressed woman gazing out (, turns into a powerful meditation on human destiny. There is not a single romantic painting that signifies what immediately is shown. Given that this is the case, do we really have good reason to assume that abstract painting as

[21] Johannes Grave, Caspar David Friedrich. Glaubensbild und Bildkritik, (Zürich: Diaphanes 2011) 109. 


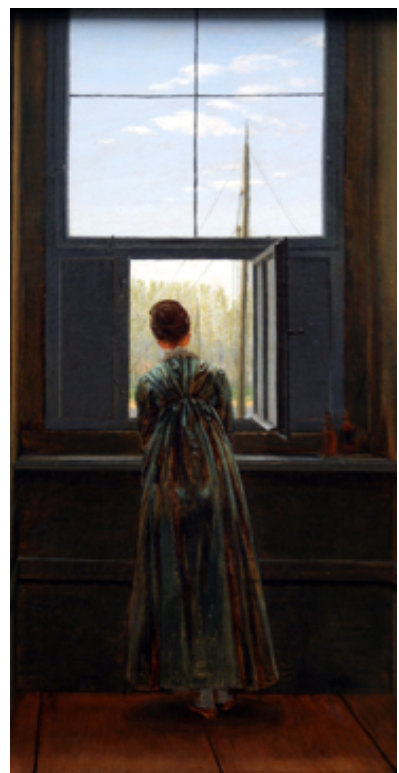

Fig. 8. Woman at a Window, 1822, detail, oil on canvas $44 \times 73 \mathrm{~cm}$ Alte Nationalgalerie, Berlin. well signifies what is immediately shown? If a figurative painting does not do so, why should an abstract painting?

Rothko's mission, according to his own words, was «the elimination of all obstacles between the painter and the idea and between the idea and the observer».22 If we think about it, we could recognize in these words the real purpose of every imago templi: i.e. the union with the divine in a transfiguration of space and time through image and art. But many Christian authors, as we said, saw a godless art in Abstract painting. ${ }^{23}$ The absence of human figure or, particularly, the absence of the figure of Christ, made this art incompatible with the Christian art canons. ${ }^{24}$ The Church Fathers always insist on saying that the abstract God of the Old Testament became really known (really revealed) only through His image. According to this logic and translating this to our terms, abstract art would be a step backward to the Jewish abstraction. As I already said, this is false because Jewish art does not want to represent the Absolute in figure. Furthermore, it is the New Testament that gives rise to what has historically been developed as an internal contradiction of Christianity. ${ }^{25}$ In the Gospel of John we can read: «no one comes

[22] Tiger's Eye, v. 1, n. 9, October 1949.

[23] Besides Seldmayr, many Orthodox thinkers considered Abstractism as a form of Atheism; see, for instance, one of the most influential among them: P. Evdokimov, L'art de l'icône: Théologie de la beauté (Paris: Desclée de Brouwer, 1970) or an Italian philosopher with a Roman-Catholic background: M. Borghesi, Secolarizzazione e Nichilismo. Cristianesimo e cultura contemporanea (Siena: Cantagalli, 2005). Contrary to this negative evaluation, but -and that is important- for the very same reasons (i.e. the loss of the Human figure, the autonomisation of the art-work, etc.), the supporters of Abstract Art admitted and hailed this new «spiritual atheism», as the most acute of them did: see, A. Kojève, Les peintures concrètes de Kandinsky (Paris: 1936).

[24] After the Second Vatican Council, the Roman Church seems to accept easily whatever claims to be Christian. But fortunately there are still voices that critically explain how a Christian art is founded on precise symbolical and liturgical requests and not on fashions. See, for instance, the important work of Juan Plazaola, Arte sacro actual. Estudio. Panorama. Documentos (Madrid: 2006). The same problem rises constantly in every art and for every great artist. In music we face the same problems by characterizing very easily something like «sacred music» only for a matter of convenience. A useful example would be the analysis of Verdi's Messa da Requiem made by the Italian scholars C. Stucchi, V. Donella, M. Capra, A. Toscani and D. Rizzo in the volume Verdi, La Musica e il Sacro. Atti del convegno, Roncole Verdi - Busseto 27-29 settembre 2013 (Fidenza: Mattioli 1885, 2014) in order to understand many actual cases as well, and -besides questions of taste-the impossibility to attribute the adjective «sacred» or «religious» to every artistic product that has only formal or only intentional similarities to what is actually established by the Church as sacred.

[25] A contradiction that the Orthodox theologians are proud to consider sublated in their Theology of 
to the Father but through Me. If you really know me, you will know my Father as well. From now on, you do know him and have seen him». ${ }^{26}$ This necessity of the «medium» gave rise to all iconophile doctrines. The expression «from now on» designates a turning point in History: it indicates and separates the aniconic Jewish past from the new figurative (because incarnated) Christian redemption. But in the same Gospel we also find the principle of every iconoclasm: «God is spirit, and those who worship Him must worship in spirit and truth». ${ }^{27}$ In Rothko's notebook, we can find his thoughts on similar questions:

Like the old ideal of God, the abstraction itself in its nakedness is never directly apprehensible to us. As in the case of God, we can know its manifestations only through works, which, while never completely revealing the total abstraction in the round, symbolize it by the manifestation of different faces of itself in works of art. Therefore, to feel beauty is to participate in the abstraction through a particular agen$c y$. In a sense, this is a reflection of the infiniteness of reality. For should we know the appearance of the abstraction itself, we would constantly reproduce only its image. As it is, we have the exhibition of the infinite variety of its inexhaustible facets, for which we should be thankful. ${ }^{28}$

In the following pages, Rothko exposes a great part of Western art history, through a main opposition: «In all art from that time on, the duality between the world of sensations and the world of the mind is the basic expression of the lack of unity». ${ }^{29}$ Rothko was completely dedicated to this search for unity. ${ }^{30}$ In another surprising text, we see him paying attention to the function of religious Aesthetics, again because of the unity that they confer in a spiritual level:

Icons. See: L. Uspensky, La théologie de l'icône dans l'Église orthodoxe (Éditions du Cerf, 1980); Greek trans-

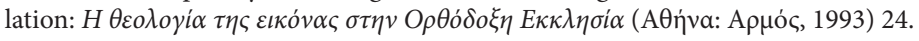

[26] John 14:6-7; italics are mine.

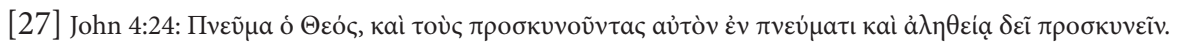

[28] See: M. Rothko, The Artist's Reality. Philosophies of Art, edited by Christopher Rothko (Yale University Press, 2006) 64-5; the text continues with this «platonic» example: «Let us consider the case of our relationship to our friends. We love them with a common love because we all participate in the common prototype of humanity, but because each human being is a new and different manifestation of this prototype we want to know more about each one. Yet we should not be able to enjoy our friends at all if they could not be referred to the common prototype, for through the recognition of this identity with the prototype are we able to make sensible observations of differences».

[29] Rothko, The Artist's Reality, 94.

[30] I believe this search is what connects Rothko directly to the Romantics-to the best of them, like Hölderlin, whose whole life was such a search for the One: «Finally the idea which unites all [previous ones], the idea of beauty, the word understood in the higher, Platonic sense. I am convinced now, that the highest act of reason, which in that it comprises all ideas is an aesthetic act, and that truth and goodness are united as sisters only in beauty.» See: Friedrich Hölderlin, Essays and letters on theory (New York: State University of New York Press, 1988) 155; Sämtliche Werke (Grosse Stuttgarter Ausgabe), edited by Friedrich Beissner. (Stuttgart: Kohlhammer, 1943-1985) IV,298. 
Today, therefore, when there is no unity, when the separation between the objective and subjective has not yet been bridged [...], we can no longer see the full face of a unified reality, but rather we must look at each profile separately: art or sensuality is one of these profiles, and philosophy or objectivity is the other. The church remains as a symbol of the need and the desire for that ultimate unity. Viewing the church in this light, we may explain the genuine feeling of those who believe that only religion, as the instigator of the arts, can produce a truly ultimate art. What they really mean is that religion is the manifestation of that ultimate unity. ${ }^{31}$

When he wrote these words, he did not yet know that in the near future he should personally attempt this unity by creating a new kind of religious art. Such an «art», paradoxically enough, did not have a «religion» to serve and, correctly, the State Historical Commission of Texas declared: «The Rothko Chapel is not required to meet Criteria Consideration A (religious properties), because the building is significant as the center of a cultural institution rather than a religious organization». ${ }^{32}$ Undoubtedly, a religious impetus characterizes the whole project, but despite the intentions of the patrons, no historical religion could practice its cult without prior architectonical modifications. ${ }^{33}$ Abstract Art and especially Rothko's art, are rather in the service of another kind of trans-historical Church.

During the dedication of the Chapel, John De Menil gave a significant speech that could mark a whole historical period: a period that is still our own historical present. He said:

Images, which were never acceptable to Jews and Muslims, have become intolerable to all of us today. It may be an important sign that we cannot represent Jesus or his apostles anymore. Any representation that is not naïve is unbearable.... Nobody is visually naïve any longer. We are cluttered with images, and only abstract art can bring us to the threshold of the divine. ${ }^{34}$

It is difficult to find better words to express our contemporary state of «visual consciousness» in its higher levels. However, we should observe again that the religious issue is always slippery, as long as neither Jews nor Muslims believe that art could bring us to the threshold of the divine. What seems to be a common aniconic result, reached

[31] Rothko, Artist's Reality, 27

[32] See supra footnote [9].

[33] The fact that today, for commercial reasons, somebody can be married there, does not demonstrate a real affinity to any religion, more than the affinity that a chapel of Las Vegas has, with an Elvis Presley-disguised priest, with the sacrament of matrimony. But just the architectural issue would be enough to close such a discussion. Just to indicate some of the many architectonical elements, necessary for the religious architecture, we can affirm surely that without a mihrab indicating the qibla, there is no Islamic temple. Without an Iconostasis (i.e. a division between the nave and the sanctuary) there is no Christian-Orthodox temple. Without a Torah ark, there is no Jewish temple.

[34] Dominique De Menil and Frances Carter Stephens, The Rothko Chapel: Writings on Art and the Threshold of the Divine. Edited by Polly Koch and Diane Planer Lovejoy (Houston: Rothko Chapel, 2010). 
by all religious traditions, in reality hides a completely different path, and as we know, it often is the path that gives sense to the destination. Out of any metaphor, we should be aware of bad abstractions that do not consider seriously the determinate negations of a developing consciousness. There is in De Menil's words a beautiful contradiction that shows exactly what I mean. It is the contradictory conviction that «images are intolerable to us» but at the same time «art can bring us to the threshold of the divine». That it is not an oriental element, it is not part of any Semitic religion, but it is typically Greek and the way Greek heritage survived in Christianity. Plotinus spoke literally of a process in which through philosophy and art we arrive at this very threshold and only then we should leave behind the images. ${ }^{35}$ "Only then» means «only when the spiritual consciousness is able to do so». It means, that if today we are not "visually naive any longer», we owe this not to a dogmatic prohibition of images that comes positively from an Authority, but, on the contrary, to a slow maturation of our own visual culture, from Xenophanes to a contemporary critique of digital images. For there is a great difference between a prohibition of image-making, a materially expressed iconoclasm by image-breaking and an internal iconoclastic development of a rich figural and visual tradition. ${ }^{36}$ However, this unique ability to practice an «iconoclastic art» is conceivable and explainable only in the frame of our Philosophical tradition. Out of it, it seems groundless and transient.

\section{The Invisible Church of Idealism.}

January 1795, Bern, Switzerland. A twenty-five-year-old private tutor writes a letter to his former roommate. He concludes the letter with a wish: «May the Kingdom of God come, and our hands not be idle»; and then he closes with this maxim: «Reason and Freedom remain our password and the Invisible Church our rallying point». ${ }^{37} \mathrm{His}$ friend's answer to this letter is even more disconcerting. At the end of his answer, the friend declares: «There is no personal God, and our highest endeavor is aimed at the destruction of our personality». ${ }^{38}$ In these letters the two young friends, Hegel and Schelling, confide, to one another, their will to overcome Lutheran orthodoxy. In order to achieve this target, they mobilize the most controversial philosophical tradition that spans from Spinoza to Lessing. The new idealistic pantheism seems to be the most coherent solution to the contradictions of modernity. Two years later, presumably in 1797, together with Hölderlin, they edited the idealistic System-Program where a new

[35] See: Plotinus, Ennead VI, 9.

[36] For a more detailed treatment of this argument, see my «A Philosophical Revision of Iconoclasm», in: Revision of Modern Aesthetics, ed. by Miško Šuvaković, Vladimir Mako, Vladimir Stevanović (Belgrade: University of Belgrade - Faculty of Architecture, 2015) 556-69.

[37] G.W.F. Hegel, The Letters (Bloomington: Indiana University Press, 1984) 32.

[38] Hegel, The Letters, 33. 
religion is announced as «monotheism of Reason and Heart» and "polytheism of imagination and art».

This new philosophical religion, in reality, is as old as the Scriptures. The sense of an Invisible Church is easily perceivable under phrases such as the one by Matthew: «many are called, but few are chosen». ${ }^{39}$ In the same Gospel, Jesus says that «not everyone who says to Me, 'Lord, Lord', shall enter the kingdom of heaven, but he who does the will of My Father (...)».40 That means that there will be a distinction between those who speak in the name of God without acting as they should (that would be the visible Church) and those who realize a virtuous life (the real and invisible Church). This idea is sustained also by the parable of the tares ${ }^{41}$ There it is explained that only God will discern and decide at the end of time who belongs to the real Church.

In reality, the term «invisible church» appeared only in 16th century, in the frame of the Religious Reformation. Particularly, it was an idea promoted by Zwingli ${ }^{42}$ and Calvin, ${ }^{43}$ and then has been adopted by many Reformed Confessions. An important testimony of this concept can be found in the «Later Helvetic Confession» (1566) which functioned as a model for many of the following confessions:

\begin{abstract}
But we do not so restrict the Church as to exclude those who from unavoidable necessity and unwillingly do not partake of the sacraments, or who are weak in faith, or still have defects and errors. God had friends even outside of the Jewish people. We know what happened to Peter, and to chosen believers from day to day, and we know that the Apostle censured the Christians in Galatia and Corinth for grave offenses, and yet calls them holy churches of Christ. Yea, God may at times by a righteous judgment allow the Church to be so obscured and shaken as to appear almost annihilated, as in the days of Elijah (1 Kings xix.18; comp. Rev. vii.4, 9); but even then he has his true worshipers, even seven thousand and more; for 'the foundation of God standeth sure, having this seal, the Lord knoweth them that are his' (2 Tim. ii.19). Hence the Church may be called invisible, not that the men composing it are invisible, but because they are known only to God, while we are often mistaken in our judgment. There are also many hypocrites in the Church, who outwardly conform to all the ordinances, but will ultimately be revealed in their true character and be cut off (1 John ii.19; Matt. xiii.24, 47). The true unity of the Church is not to be sought in ceremonies and rites, but in the truth and in the catholic faith, as laid down in the Scriptures and summed up in the Apostles' Creed. Among the ancients there was a great diversity of rites without dissolving the unity of the Church. ${ }^{44}$
\end{abstract}

[39] Matt. (22:14).

[40] Matt. (7:21).

[41] Matt. (13:24-30).

[42] See Zwingli's Exposition of the Christian Faith (written in 1531, and published in 1536); for the Latin text, see: Collectio confessionum in ecclesiis reformatis publicatarum, ed. by H. A. Niemeyer (Leipzig: 1840). Zwingli exposes the same distinction, but without the specific terminology in his earlier Confession to Charles V.

[43] See: Calvin, Institutio christianae religionis, Book IV, Chapter I., $\$ 7$.

[44] See: Harmonia confessionum fidei, orthodoxarum \& reformatarum Ecclesiarum; English translation in: The harmony of Protestant confessions, translated by P. Hall (London: 1842) 215-6; our translation is slightly modified. 
Hegel and Schelling, as former students of Theology, probably knew this doctrine well. But their professors were not only simply theologians but Kantian followers as well. Thus, I believe, the place where he could have found a philosophical explanation and a reference to the «invisible church» is Kant's treatise Religion within the boundaries of mere reason, published in 1793, two years before the correspondence mentioned above. There, we discover that Hegel's words were literally taken by Kant, inasmuch as his wish on the Kingdom of God, is the phrase with which Kant begins his exam:

the wish of all well-disposed human beings is, therefore, 'that the kingdom of God come, that His will be done on earth'; but what preparations must they make in order that this wish come to pass among them ${ }^{45}$

Further, Kant defines the invisible church as the «mere idea of the union of all upright human beings under direct yet moral divine world-governance». But while for Kant the real Church was the visible one, as the only possibility of finite beings to be realized partially, the young idealists turned upright what was down. To this purpose, the mediation of Fichte was crucial. For Kant the «moral divine world-governance» was a mere idea. But for Fichte was the only true and actual faith. «This moral order is what we are assuming to be divine ${ }^{46}$ and he continues: «that living and active moral order is itself God; we require no other God and can grasp no other». ${ }^{47}$ After his lectures at Jena in 1798, this phrase cost him a serious accusation of atheism that gave rise to what is known as the Atheismusstreit. This happened because freedom and personality of God were absorbed in a new immanent determinism similar to what Spinoza taught in his geometrically ordered Ethics. In fact, in the same writing, Fichte explained that:

you simply do not and cannot think of personality and consciousness without limitation and finitude. Consequently, by attributing these predicates to this being you make it into something finite, into a being similar to yourselves; and you have not thought of God, as you wished, but rather you have only multiplied yourselves in your thinking. ${ }^{48}$

These are the ultimate consequences of the thought implicit in the words of the two young friends that we saw at the beginning: in order to gain the entrance to the Invisible Church, the notion of personality has to be sacrificed. Schelling became a passionate follower of these ideas, but Hegel soon, focused on how to find a way to overcome this opposition through a higher concept of «subject».

[45] I. Kant, Religion within the boundaries of mere reason, in Id., Religion and Rational Theology, (Cambridge: Cambridge University Press, 1996), 135.

[46] J.G. Fichte, «On the Ground of Our Belief in a Divine World-Governance», in J.G. Fichte and the Atheism Dispute (1798-1800), edited by Yolanda Estes and Curtis Bowman, (Ashgate, 2010) 25.

[47] J.G. Fichte, «On the Ground of Our Belief...», 26.

[48] J.G. Fichte, «On the Ground of Our Belief...», 26. 


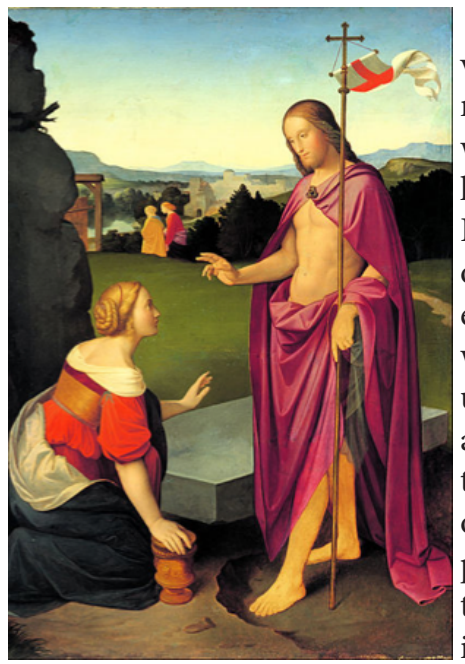

Fig. 9. J. F. Overbeck, Easter Morning, 1818. Detail.

Oil on canvas, $1020 \times 1310 \mathrm{~cm}$, Museum Kunstpalast, Düsseldorf.

Impersonality of God, prohibition of the visual representation, and overestimation of the immediacy are strictly related. But Hegel's revolution was to conceive «the true not as substance, but equally also as subject». ${ }^{49}$ This subject is not the Kantian or Fichtian «I», but a dialectical result that conserves the opposition of subject/object. ${ }^{50}$ If symbolism expresses inwardness, while realism expresses the external world, then who could represent their dialectical union and how? For Hegel, this difficulty is already announced in the main problem of Christian art, i.e. the representation of the highest paradox, the death of God in human figure. Hegel keeps firmly on this principle: «Christ [...] passing away in the agony of a torturing and slow death-this cannot be portrayed in the forms of Greek beauty». ${ }^{51}$ To affirm that we have to leave Beauty behind is the first step to our Modern Art. Nazarene movement, for instance, attempted a revival of Italian Renaissance (See Fig. 9), while Hegel on the contrary was saying that no Homer, Dante or Shakespeare can appear in our day, ${ }^{52}$ because «these are materials [...] which have been sung once and for all. Only the present is fresh, the rest is paler and paler». ${ }^{53} \mathrm{He}$ criticized decisively those who keep representing God in the perfection of Greek measures:

Every time those artists have proceeded in the worst possible way who have attempted to make out of Christ an ideal in the sense and in the manner of the classical ideal. (...) Christ should have on the one hand subjective personality and individuality, and, on the other, inwardness and purely universal spirituality; both these characteristics are inconsistent with the imprint of bliss on the visible aspect of the human form. To combine both these extremes in expression and form is of supreme difficulty, and painters especially found themselves in perplexity every time they departed from the traditional type. ${ }^{54}$

Hegel captures here a great problem: he foresaw that the departure from the tradition will create an embarrassing result for the visible church, and we can have a

[49] See: Hegel's Preface to the Phenomenology of Spirit, translation and running commentary by Yirmiyahu Yovel, (Princeton and Oxford: Princeton University Press, 2005) 95.

[50] See the commentary of Yovel, in: Hegel's Preface to the Phenomenology of Spirit, 95.

[51] Aesth., I, 538.

[52] Aesth., I, 608.

[53] Aesth., I, 608.

[54] Aesth., I, 536. 
confirmation looking to contemporary religious art, as the chapel of Notre Dame du Haut, in Ronchamp, France, designed by Le Corbusier in the 50's. But how could we not observe that an apse as that of the altar of Notre Dame du Haut appeared in history only once, that is to say, during the Iconoclastic period, in churches like Hagia Irene of Constantinople. That, however, happened in a period of a great internal Religious clash and in art-works that later would be condemned as heretical. It should be obvious that the new Religious art does not belong to the visible Church anymore. Through modern and contemporary art, what for centuries was a mere word-predication of the Invisible Church, came suddenly into light and established a real correspondence in the hearts of many people, while the old visible Church, by accepting grains of modernism, seems to be tired and in full decay. ${ }^{55}$

The artistic freedom from any content and any prescription was realized slowly after Hegel's death. But if we pay attention to his words, we can recognize already the rules of Abstraction:

[This] is the effect and the progress of art itself which, by bringing before our vision as an object its own indwelling material, at every step along this road makes its own contribution to freeing art from the content represented. What through art or thinking we have before our physical or spiritual eye as an object has lost all absolute interest for us if it has been put before us so completely that the content is exhausted, that everything is revealed, and nothing obscure or inward is left over any more. ${ }^{56}$

Here it becomes clear that his statement regards more the future, Abstract Expressionism in particular, than the arts of his time. It was Rothko's generation that declared spontaneously the end of Art and they assumed their freedom as the condition to enter in a higher region of the Spirit. But this «end» began more than a hundred years before, when Caspar David Friedrich defended Hegelian Aesthetics by saying that what he expects from art is «elevation of spirit and religious impetus». These are, among others, the very elements that brought Art up to its end, and of course in a completely different sense than the one given commonly to this notion. For, the expression "to come to an end», if translated in Greek (thus: to come to a telos) could also have the meaning «to be realized». This double sense of the word «telos», that spans between «end» and «realization», is what Hegel has in mind when he advocates about an internal teleology. The end of art is the full realization of Art itself in this philosophical Invisible Church. The following words of Hegel, pronounced two hundred years ago, are still fresh like our present:

The great artist today needs in particular the free development of the spirit; in that development all superstition, and all faith which remains restricted to determinate forms of vision and presentation, is degraded into mere aspects and features. [...]. In this way every form and every material is now

[55] The desperate call to the artists in the Second Vatican Council, seems to me to be such a sign of decay, much better than an «opening» to the secular society; see: J. Plazaola, Arte sacro actual (Madrid: 2006) 481 ff.

[56] Aesth., I, 604. 
at the service and command of the artist whose talent and genius is explicitly freed from the earlier limitation to one specific art-form. ${ }^{57}$

\section{The resurgence of the subject.}

Now, let us put some Wegmarken, in order to summarize what has been sporadically said during our comparative exposition. These "path-marks», necessary to not lose our way, namely are: the impossibility of Beauty; the refusal of naturalism; the spiritual impetus; the dissolution of any restrictive art-form; the freedom to use the materials however the artist wants; and, finally, the resurgence of a different kind of Subject. These are some of the main points that are common in the practices of both Romantic and Abstract traditions and that Hegel theorized explicitly.

It seems natural that the visible church searches for a material subject in the picture. I think that if the human figure has to disappear, it is not because there is no faith to the subject anymore. On the contrary, another kind of relationship for the human subject has to be established and another conception of the subject has to be conceived. Our concern is not the «subject-represented», but the «subject of the vision». The observer of a painting has to participate in the very life of the painting. Not through ridiculous performances, but through a real devotion. Rothko said that «a picture lives by companionship». ${ }^{58}$ We could go further by saying that the picture ontologically needs the observer. I would say that only in the eyes of the observer, the picture becomes image: the materially determinate configuration of shapes and colours becomes object of the Spirit, immaterial, not only a visual but a total and synaesthetic experience.

For that reason, the picture should not create an illusion of reality. In 1943, Rothko, Newman and Gottlieb signed a Manifesto where they declared that they "wish to reassert the picture plane». «We are», they said, «for flat forms because they destroy illusion and reveal truth». ${ }^{59}$ This is a very profound insight that gives a religious character to abstract expressionism. The subject is not a humanoid, made of lines and colors, but the centre where the experience of contradiction takes place and is sustained. Hegel had said that «a being which is capable of containing and enduring its own contradiction is a subject; this constitutes its infinitude». ${ }^{60}$ In other words, only he/she who is conscious of the proper finitude, is already able to overcome it. Translated into an artistic language, it means that flat forms could express better the contra-

[57] Aesth., I, 606.

[58] Tiger's Eye, volume 1, number 2, December 1947, 44.

[59] Brief manifesto: Mark Rothko, with Adolph Gottlieb and Barnett Newman, June 13, 1943, edition of the New York Times.

[60] Hegel's Philosophy of Nature, 3 volumes, translated and edited by M.J. Petry (London: Allen \& Unwin 1970) \$359 Remark. 
diction of an entity that by experience is known to be three-dimensional. Because the point is not to reproduce the living subject as a hologram, but to understand better in figure its metaphysical properties.

The fifth article of the same Manifesto, says: «We assert that the subject is crucial and only that subject matter is valid which is tragic and timeless». Tragedy and Eternity. Subject and Substance. Man and God. And between them, the art of painting as a privileged religious act. To remind us that only in this polarity the human being becomes a real Subject. This is not rhetoric. Every modern syncretism and pseudo-mysticism, claim to see God everywhere and a monochrome panel becomes an icon only because it is empty as much as their minds. For Hegel, Schelling was the main person responsible of this «totally monochromatic painting», ${ }^{61}$ because he did not know how to unify the differences and hid them in the pure Identity, in a «dead understanding». The abstract art, not differently than every other kind of art, as immediate product, is nothing more than this void. But to follow its history and the ideas that led history, means to understand it as a result and as a synthesis of greater spiritual forces that are shaping our civilization, and not only single galleries, museums, or private mystical experiences.

The secularized pseudo-mysticism invites us to enter in the painting and «lose ourselves». Against this trivial view of art, we could quote Newman's words, spoken during an interview. He said: «the onlooker in front of my painting knows that he is there; to me the sense of place not only has a mystery but has that sense of metaphysical fact». ${ }^{62}$ In that sense I claim that «Abstraction» is not a way to «lose ourselves» but to "find ourselves». But that means to find and to deal with whatever is there, even if there is no-thing. Who could be ready to ask so much from a painting? Or to accept, suddenly, that he/she does not see anything there, just because his/her proper glance is empty. It will always be easier to attribute the failure to the painting than to ourselves.

In the loneliness of Rothko Chapel we can find the call of idealism to the inwardness of the Spirit, as much as this very void of our existence. A black painting could be a mirror of nothing, but could also reveal our necessity to capture in form the formless. After all, is not this the very essence of the image? To be completely given into visibility is proper to the idol. But to reflect one's glance is the beautiful-and terrible at once-essence of the real image. This Iconostasis of the Invisible Church is not addressed to secular or religious eyes, but, beyond this opposition, to those who still secretly celebrate "Reason and Freedom». If our eyes are void, that is another question.

[61] Hegel's Preface to the Phenomenology of Spirit, 164.

[62] Newman, Selected Writings and Interviews, 257. 
